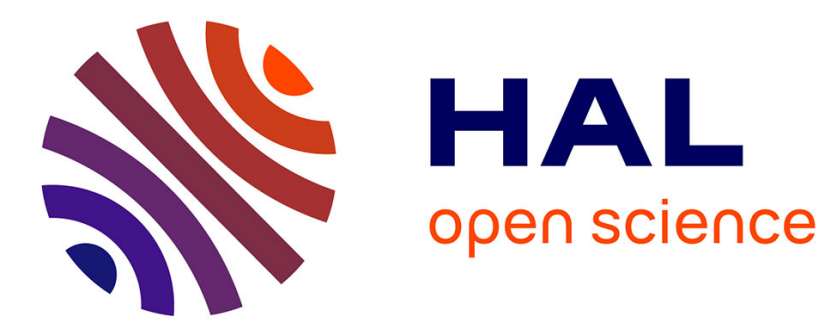

\title{
Crystallographic and (spectro)electrochemical characterizations of cobalt(II) 10-phenyl-5,15-di-p-tolylporphyrin
}

Abdou K.D. Dimé, Hélène Cattey, Dominique Lucas, Charles H. Devillers

\section{To cite this version:}

Abdou K.D. Dimé, Hélène Cattey, Dominique Lucas, Charles H. Devillers. Crystallographic and (spectro)electrochemical characterizations of cobalt(II) 10-phenyl-5,15-di-p-tolylporphyrin. Journal of Molecular Structure, 2021, 1226, pp.129321. 10.1016/j.molstruc.2020.129321 · hal-03419626

\section{HAL Id: hal-03419626 \\ https://hal.science/hal-03419626}

Submitted on 8 Nov 2021

HAL is a multi-disciplinary open access archive for the deposit and dissemination of scientific research documents, whether they are published or not. The documents may come from teaching and research institutions in France or abroad, or from public or private research centers.
L'archive ouverte pluridisciplinaire HAL, est destinée au dépôt et à la diffusion de documents scientifiques de niveau recherche, publiés ou non, émanant des établissements d'enseignement et de recherche français ou étrangers, des laboratoires publics ou privés. 


\title{
Crystallographic and (spectro)electrochemical characterizations of cobalt(II) 10-phenyl-5,15-di-p-tolylporphyrin
}

\author{
Abdou K. D. Dimé, ${ }^{* a}$ Hélène Cattey, ${ }^{b}$ Dominique Lucas ${ }^{b}$ and Charles H. Devillers*b \\ ${ }^{a}$ Département de Chimie, UFR SATIC, Université Alioune Diop de Bambey, Diourbel, BP 30, \\ Sénégal. \\ ${ }^{b}$ Institut de Chimie Moléculaire de l'Université de Bourgogne UMR6302, CNRS, Univ. \\ Bourgogne Franche-Comté, 9 avenue Alain Savary, 21000 Dijon, France;
}

\begin{abstract}
The synthesis, cyclic and rotating disk electrode voltammograms, UV-visible absorption and Xray diffraction analyses of cobalt(II) 10-phenyl-5,15-di-p-tolylporphyrin (1-Co) are described. 1Co was crystallized by slow diffusion of $n$-hexane into a concentrated $\mathrm{CH}_{2} \mathrm{Cl}_{2}$ solution. X-ray diffraction analyses reveals porphyrin aromatic cycle stacking in the crystal, $\mathrm{C}-\mathrm{H} \cdots \pi$ interactions of the $\mathrm{CH}_{2} \mathrm{Cl}_{2}$ solvent with the $\pi$-system of one tolyl group and $\mathrm{Co}(\mathrm{II}) \cdots \pi$ (porphyrin ring) interactions. The abstraction of $1.0 \mathrm{~F} / \mathrm{mol}$ during the electrolysis at the first oxidation potential was followed by spectroelectrochemistry. It leads to the $\mathrm{Co}(\mathrm{II}) \rightarrow \mathrm{Co}$ (III) transformation rather than the formation of the cation radical of the porphyrin ligand. These results were supported by comparison of the cyclic and rotating disc electrode voltammograms, of the UV-Visible absorption spectra, before and after electrolysis of 1-Co.
\end{abstract}

\section{Keywords}

X-ray crystallographic structure; Cobalt, Porphyrin; Electrosynthesis; stacked aromatics dimers; $\mathrm{C}-\mathrm{H} \cdots \pi$ interactions;-Co(II) $\cdots \pi$ interactions

\footnotetext{
*Corresponding authors

E-mail address: abdou.dime@uadb.edu.sn (A. K. D. Dimé)

E-mail address: charles.devillers@u-bourgogne.fr (C. H. Devillers).
} 


\section{Introduction}

Porphyrins have been the subject of intense researches in numerous fields due to their essential role in natural processes such as photosynthesis and oxygen transport in blood. These macrocycles have found applications in material science, (electro)catalysis, energy converting devices and medicine [1-16]. There properties can be easily adapted to specific applications by introducing new metal cations in the center of the porphyrin ring or by chemical functionalization of the porphyrin periphery $[17,18]$. Cobalt porphyrins and corroles have attracted much attention in recent years, both because the cobalt metal exhibits several oxidation states and porphyrins can generally stabilize the central metal cations in their high oxidation states $[19,20]$. Electrocatalytic four electrons reduction of $\mathrm{O}_{2}$ to $\mathrm{H}_{2} \mathrm{O}$ by cobalt porphyrins has been extensively studied so far not only because of its biological relevance, but also due to its technological significance such as in fuel cells [21, 22]. Furthermore, the studies of cobalamin and its derivatives/analogues have significantly contributed to increase the popularity of Co(II) complexes [23-26]. It was also found that the reactivity of axial ligation of cobalt porphyrin play a pivotal role in a number of bio- and 'bio-inspired' catalytic transformations. In 2018, Kadish and co-workers showed that equilibria involving the $\mathrm{Co}$ (III) derivative radical and the $\mathrm{Co}$ (II) porphyrin $\pi$-cation radical depends on the nature of a solvent and/or substituent [27-30]. In this context, it is important to know precisely the role of the various species involved in the mechanism and to control their reactivity. This requires a very fine description of each step, with the identification of the intermediates, the investigation of the reactivity of the electrogenerated species through cyclic and rotating disc electrode voltammetry analyses and preparative electrolyses. The work reported by Manassen elucidated the mechanism of the electrochemical oxidation of cobalt (II) meso-tetraphenylporphyrin (CoTPP) in $\mathrm{CH}_{2} \mathrm{Cl}_{2}$ by cyclic voltammetry [31]. In this report, it was clearly demonstrated that the first oxidation of CoTPP is centered on the metal ( $\mathrm{Co}(\mathrm{II}) \rightarrow \mathrm{Co}(\mathrm{III})$ ), while the two others correspond to the oxidation of the porphyrin ring.

As part of our on-going interest focused on the electrochemical reactivity of porphyrin complexes [15, 32-38], this work intends to study the electrochemical response and reactivity of cobalt(II) 10-phenyl-5,15-di-p-tolylporphyrin (1-Co, Scheme 1). Thus, in this manuscript, we report the synthesis, the electrochemical and X-ray crystallographic characterizations of 1-Co. 


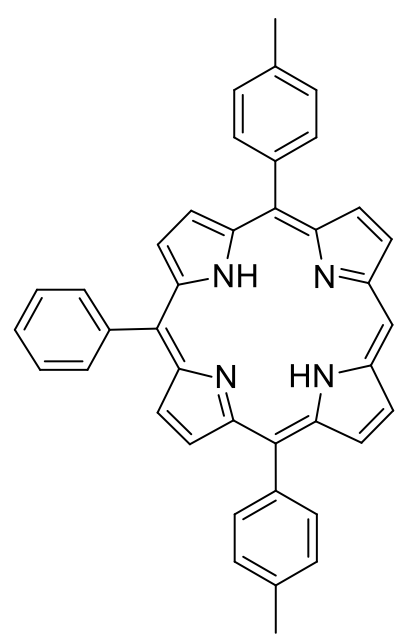

$1-\mathrm{H}_{2}$

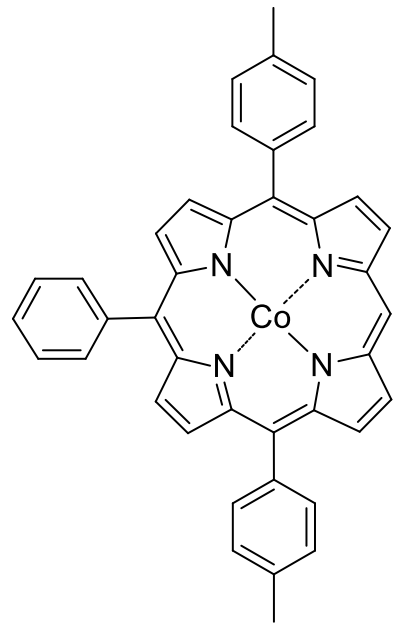

1-Co

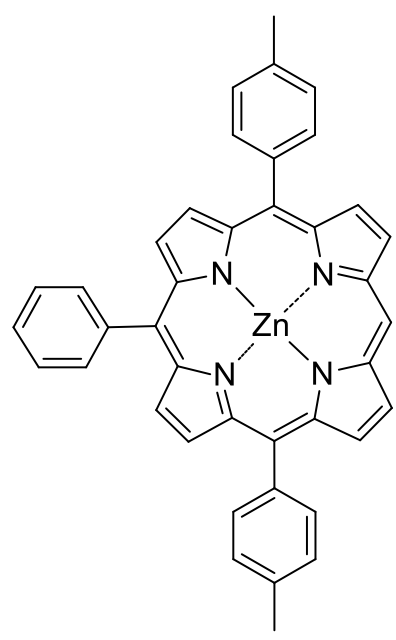

$1-\mathrm{Zn}$

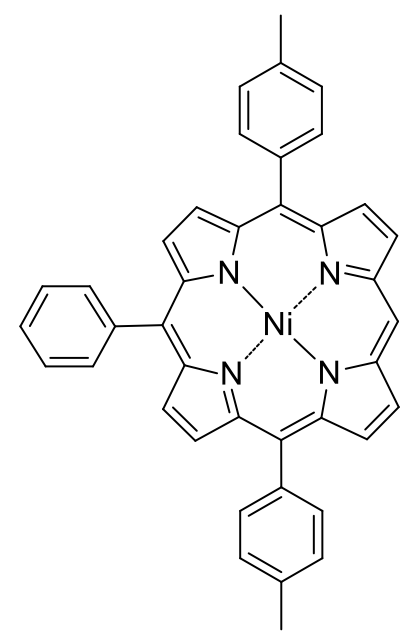

$1-\mathrm{Ni}$

Scheme 1. Free base porphyrin 1-H2 [39] and its corresponding metal complexes 1-Co, 1-Zn [34] and 1-Ni [35].

\section{Experimental}

\subsection{X-ray equipment and refinement}

Diffraction data were collected on a Nonius KappaCCD diffractometer equipped with a nitrogen jet stream low-temperature system (Oxford Cryosystems). The X-ray source was graphitemonochromated Mo- $K_{\alpha}$ radiation $(\lambda=0.71073 \AA$ ) from a sealed tube. Data were reduced by using DENZO software without applying absorption corrections; the missing absorption corrections were partially compensated by the data scaling procedure in the data reduction. The structure was solved by direct methods using the SIR92 [40] program and refined with full-matrix least-squares on $F^{2}$ using the SHELXL97 [41] program with the aid of the WIN-GX [42] program suite. All nonhydrogen atoms were refined with anisotropic thermal parameters. Hydrogen atoms attached to carbon atoms were included in calculated positions and refined as riding atoms. The molecular structure of 1-Co has been determined by X-ray diffraction analyses. Crystal data, data collection and structure refinement details are given in Table 1. CCDC-2006293 contains the supplementary crystallographic data for this paper. These data can be obtained free of charge via https://www.ccdc.cam.ac.uk/structures/ (or from the Cambridge Crystallographic Data Centre, 12, Union Road, Cambridge CB2 1EZ, UK; fax: +44 1223 336033). 


\section{Table 1}

Crystal data and structure refinement for 1-Co.

\begin{tabular}{|c|c|}
\hline Empirical formula & $2 \mathrm{C}_{40} \mathrm{H}_{28} \mathrm{CoN}_{4}, \mathrm{CH}_{2} \mathrm{Cl}_{2}$ \\
\hline Formula weight & 1332.11 \\
\hline Temperature & $115(2) \mathrm{K}$ \\
\hline Wavelength & $0.71073 \AA$ \\
\hline Crystal system & Triclinic \\
\hline Space group & $P-1$ \\
\hline \multirow[t]{3}{*}{ Unit cell dimensions } & $a=13.3891(3) \AA \quad \alpha=85.3960(10)^{\circ}$. \\
\hline & $b=15.1644(4) \AA \quad \beta=82.5310(10)^{\circ}$. \\
\hline & $c=15.5628(4) \AA \quad \gamma=88.6860(10)^{\circ}$. \\
\hline Volume & $3122.67(13) \AA^{3}$ \\
\hline$Z$ & 2 \\
\hline Density (calculated) & $1.417 \mathrm{Mg} / \mathrm{m}^{3}$ \\
\hline Absorption coefficient & $0.673 \mathrm{~mm}^{-1}$ \\
\hline$F(000)$ & 1376 \\
\hline Crystal size & $0.25 \times 0.05 \times 0.05 \mathrm{~mm}^{3}$ \\
\hline Theta range for data collection & 1.53 to $27.47^{\circ}$ \\
\hline \multirow[t]{3}{*}{ Index ranges } & $-17<=h<=16$ \\
\hline & $-17<=k<=19$ \\
\hline & $-20<=l<=20$ \\
\hline Reflections collected & 19132 \\
\hline Independent reflections & $13942[R($ int $)=0.0541]$ \\
\hline Completeness to theta $=27.47^{\circ}$ & $97.4 \%$ \\
\hline Max. and min. transmission & 0.9671 and 0.8499 \\
\hline Refinement method & Full-matrix least-squares on $F^{2}$ \\
\hline Data / restraints / parameters & 13942 / 0 / 842 \\
\hline Goodness-of-fit on $F^{2}$ & 1.196 \\
\hline Final $R$ indices $[I>2 \operatorname{sigma}(I)]$ & $R 1=0.0803, w R 2=0.1649$ \\
\hline$R$ indices (all data) & $R 1=0.1417, w R 2=0.1982$ \\
\hline Largest diff. peak and hole & 0.553 and $-0.956 \mathrm{e} . \AA^{-3}$ \\
\hline
\end{tabular}




\subsection{Reagents and instrumentation}

Tetraethylammonium hexafluorophosphate $\left(\mathrm{TEAPF}_{6}\right.$, Fluka puriss., electrochemical grade, $\geq 99.0 \%$ ) was used as received. $\mathrm{CH}_{2} \mathrm{Cl}_{2}$ (Carlo Erba 99.5\%) and $\mathrm{CH}_{3} \mathrm{CN}$ (SDS, Carlo Erba, HPLC gradient 99.9\%) were distilled from $\mathrm{P}_{2} \mathrm{O}_{5}$ and $\mathrm{CaH}_{2}$ respectively.

UV-visible absorption spectra were obtained with a Varian UV-vis spectrophotometer Cary 50 scan using quartz cells (Hellma). In spectroelectrochemical experiments, an UV-vis immersion probe (Hellma, $l=2 \mathrm{~mm}$ ) was connected through two optical fibers to the spectrophotometer.

All electrochemical manipulations were performed using Schlenk techniques in an atmosphere of dry oxygen-free argon at room temperature $(T=293 \mathrm{~K} \pm 3 \mathrm{~K})$. The supporting electrolyte was degassed under vacuum before use and then dissolved to a concentration of $0.1 \mathrm{~mol} \mathrm{~L}^{-1}$. Voltammetric analyses were carried out in a standard three-electrode cell, with an Autolab PGSTAT $302 \mathrm{~N}$ potentiostat, connected to an interfaced computer that employed Electrochemistry Nova software. The reference electrode was a saturated $\mathrm{KCl}$ calomel electrode (SCE) separated from the analyed solution by a sintered glass disk filled with the background solution. The auxiliary electrode was a platinum wire separated from the analysed solution by a sintered glass disk filled with the background solution. For all voltammetric measurements, the working electrode was a platinum disk electrode $(\varnothing=2 \mathrm{~mm})$. In these conditions, when operating in a mixture of $\mathrm{CH}_{2} \mathrm{Cl}_{2} / \mathrm{CH}_{3} \mathrm{CN} 2 / 3\left(0.1 \mathrm{M} \mathrm{TEAPF}_{6}\right)$ the formal potential for the $\mathrm{Fc}^{+} / \mathrm{Fc}$ couple was found to be $+0.40 \mathrm{~V} v s$. SCE.

Bulk electrolyses were performed in a three compartment cell with glass frits of medium porosity with an Amel 552 potentiostat coupled with an Amel 721 electronic integrator. A platinum wire spiral $(l=53 \mathrm{~cm}, \varnothing=1 \mathrm{~mm})$ was used as the working electrode, a platinum plate as the counter electrode and a saturated calomel electrode as the reference electrode. Electrolyses were followed by TLC and UV-visible absorption measurements.

\subsection{Synthesis and crystallization}

10-phenyl-5,15-p-ditolyl-porphyrin (1-H2, see reference [31] for its preparation) (450 $\mathrm{mg}, 0.79$ mmol) was dissolved under argon in $100 \mathrm{~mL}$ of $\mathrm{CHCl}_{3} / \mathrm{CH}_{3} \mathrm{OH}$ mixture $(1 / 1 \mathrm{v} / \mathrm{v})$ in the presence of 2.0 equivalents of cobalt acetate tetrahydrate and 2.5 equivalents of sodium acetate [43]. The resulting solution was then heated at reflux for $2 \mathrm{~h} \mathrm{[30].} \mathrm{At} \mathrm{the} \mathrm{end} \mathrm{of} \mathrm{the} \mathrm{reaction,} \mathrm{the} \mathrm{crude} \mathrm{product}$ 
was washed three times with water $\left(3 \times 200 \mathrm{~mL}\right.$ ) then dried over $\mathrm{MgSO}_{4}$. The organic phase was evaporated to dryness and the residue was purified on a silica plug $\left(\mathrm{CH}_{2} \mathrm{Cl}_{2}\right.$ as eluent $)$. The cobalt porphyrin was isolated in $70 \%$ yield $(342.5 \mathrm{mg}, 0.55 \mathrm{mmol})$. Suitable crystals for X-ray diffraction studies were obtained by slow diffusion of $n$-hexane into a $\mathrm{CH}_{2} \mathrm{Cl}_{2}$ solution of 1-Co. MALDI-TOF MS (dithranol): $[\mathrm{M}]^{+}=622.98 ; 623.16$ calc. for $\mathrm{C}_{40} \mathrm{H}_{28} \mathrm{~N}_{4} \mathrm{Co}$. UV-visible $\left(\mathrm{CH}_{2} \mathrm{Cl}_{2}\right): \lambda$ max $(\mathrm{nm})(\varepsilon$, $\%)=524(100), 407(6.3)$.

\section{Results and discussion}

\subsection{Crystallographic structure of 1-Co}

The three-dimensional molecular view of 1-Co is presented in Fig. 1. Two structurally different porphyrins (porphyrin 1 and porphyrin 2) exist in the crystal. Both porphyrins exhibit a saddledshape distortion and no axial ligand is coordinated on the cobalt(II) atom as observed by Martins and co-workers for CoTPP.( $\left.\mathbf{C H}_{2} \mathbf{C l}_{2}\right)_{\mathbf{0 . 6}}$ (CCDC 864256) [44]. In our case, one methylene chloride molecule per two porphyrins was found in the crystal lattice. Selected data are also given in Table 2 and are compared with two published structures of CoTPP without any coordinating ligands (CCDC 864256 [44] and CCDC 603708[45]). It must be stressed that when a coordinating molecule is present, it generally occupies the axial position of the cobalt porphyrin [28-29].

The RMS deviation for 1-Co $(0.212$ and $0.203 \AA$, Table 2$)$ is lower than those calculated for CoTPP. $\left(\mathbf{C H}_{2} \mathbf{C l}_{2}\right)_{0.6}(0.419 \AA$ [44] and CoTPP (0.251 $\AA$ [45]). However, the distance between the metal cation and the mean plane of the porphyrin is quite similar for these cobalt complexes (0.002(2), 0.008, $0.000 \AA$ for 1-Co, CoTPP. $\left(\mathbf{C H}_{2} \mathbf{C l}_{2}\right)_{\mathbf{0 . 6}}$ and CoTPP, respectively) but also in comparison with the corresponding 1-Zn and 1-Ni complexes $(0.0100(15)$ and $0.007(3) \AA$, respectively, [34, 35]. For 1-Co, the metal-N distance $(1.953(4)<d<1.966(4) \AA)$ is quite similar to CoTPP (1.949(2) Å), CoTPP. $\left(\mathbf{C H}_{2} \mathbf{C l}_{2}\right)_{0.6}(1.924(5)<d<1.967(6) \AA)$ and 1-Ni $(1.936(5)<d<$ $1.942(5) \AA$ ) but shorter than observed for the zinc(II) analogue $\mathbf{1 - Z n}(2.034(3)<d<2.039(3) \AA)$. 


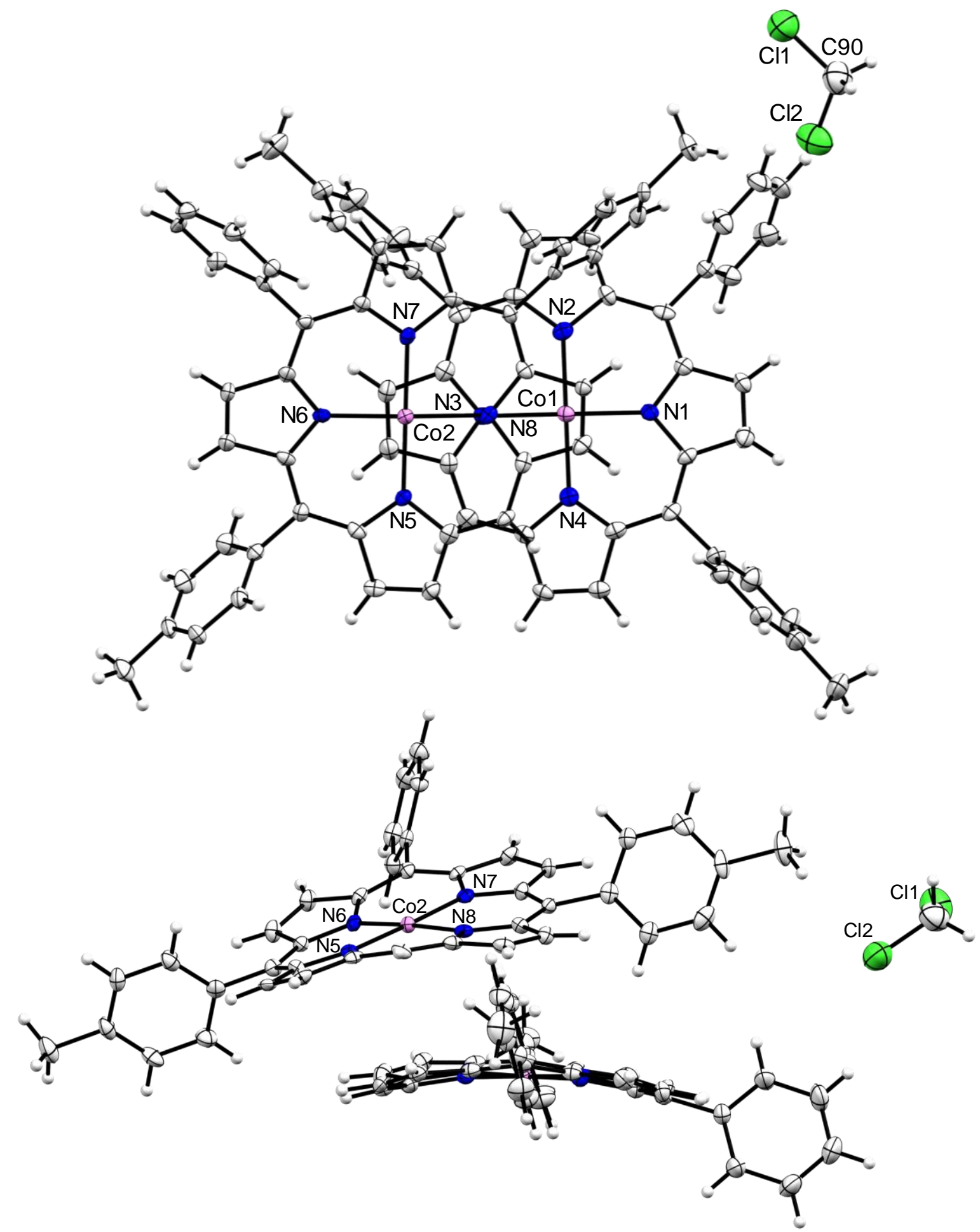

Fig. 1. Mercury views of 1-Co X-ray crystallographic structure [Color code: $\mathrm{C}$ grey, $\mathrm{N}$ blue, $\mathrm{Cl}$ green, Co pink]. Thermal ellipsoids are scaled to the 50\% probability level.

The torsion angle between the phenyl groups and the porphyrin plane is close to orthogonality in CoTPP $\left(80.21(10)^{\circ}\right)$, presents some important variation in $\mathbf{C o T P P} .\left(\mathbf{C H}_{2} \mathbf{C l}_{2}\right)_{0.6}$ (from 
$51.63(41)^{\circ}$ to $\left.83.74(14)^{\circ}\right)$ and ranges from $62.87(13)^{\circ}$ to $70.08(16)^{\circ}$ for 1-Co. For the tolyl groups of 1-Co, the torsion angle with the porphyrin ring ranges from $61.85(14)$ to $74.98(11)^{\circ}$ which are intermediate values as compared to the analogue zinc(II) complex 1-Zn (from 84.59(9) ${ }^{\circ}$ to $88.69(9)^{\circ}$, Table 2 [34]) and nickel(II) porphyrin 1-Ni (from $66.69(17)^{\circ}$ to $69.03(18)^{\circ}$, Table 2

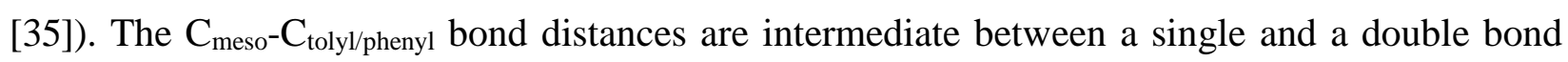
$\left(1.485(7)<d\left(\mathrm{C}_{\text {meso }}-\mathrm{C}_{\text {tolyl } / \text { phenyl }}\right)<1.508(8) \AA\right)$ and compare well with those measured for CoTPP $(1.502(4) \AA)$, CoTPP. $\left(\mathbf{C H}_{2} \mathbf{C l}_{2}\right)_{0.6}\left(1.495(7)<d\left(\mathrm{C}_{\text {meso }}-\mathrm{C}_{\text {phenyl }}\right)<1.513(9) \AA\right), \mathbf{1 - Z n}(1.501(4)<d<$ $1.504(5) \AA)$ and 1-Ni $(1.479(8)<\mathrm{d}<1.500(8) \AA)$.

The $\mathrm{CH}_{2} \mathrm{Cl}_{2}$ solvent used for the crystallization process interacts with both porphyrins via $\mathrm{C}$ $\mathrm{H}^{\cdots} \cdots \pi$ interactions $(d(\mathrm{C} 90-\mathrm{H} 90 \mathrm{~A} \cdots$ centroid $(\mathrm{C} 34-\mathrm{C} 35-\mathrm{C} 36-\mathrm{C} 37-\mathrm{C} 38-\mathrm{C} 39)=3.941(8) \AA$ and $d(\mathrm{C} 90-\mathrm{H} 90 \mathrm{~B} \cdots$ centroid(C60-C61-C62-C63-N6) $=3.769(8) \AA$ A) with the corresponding $\mathrm{C}-\mathrm{H} \cdots$ centroid angles equal to $150.3(5)^{\circ}$ and $153.1(4)^{\circ}$, respectively (see Fig. 2). These values are in the range of those typically measured for this type of weak interactions [46]. 
Table 2

Selected structural parameters for 1-Co.

\begin{tabular}{|c|c|c|c|c|c|}
\hline & 1-Co & $\begin{array}{c}\mathbf{C o T P P} .\left(\mathbf{C H}_{2} \mathbf{C l}_{2}\right)_{0.6} \\
{[44]}\end{array}$ & CoTPP [45] & 1-Zn [34] & 1-Ni [35] \\
\hline $\begin{array}{l}d\left(\text { Metal-mean }^{-m}(\AA)\right. \\
\left.\text { plane }_{\mathrm{N}}\right)^{a}(\AA)\end{array}$ & $\begin{array}{l}0.002(2) \text { (porphyrin } \\
\text { 1) / } 0.019(2) \\
\text { (porphyrin 2) }\end{array}$ & 0.008 & 0.000 & $0.0100(15)$ & $0.007(3)$ \\
\hline$d($ Metal-N) $(\AA)$ & $\begin{array}{c}1.953(4)<d< \\
1.966(4)\end{array}$ & $\begin{array}{c}1.924(5)<d< \\
1.967(6)\end{array}$ & $1.949(2)$ & $\begin{array}{c}2.034(3)<d \\
<2.039(3)\end{array}$ & $\begin{array}{c}1.936(5)<d \\
<1.942(5)\end{array}$ \\
\hline $\begin{array}{l}\mathrm{Ph} \text { torsion } \\
\text { angles }^{b}\left({ }^{\circ}\right)\end{array}$ & $\begin{array}{l}\text { 70.08(16) (porphyrin } \\
\text { 1) / 62.87(13) } \\
\text { (porphyrin 2) }\end{array}$ & $\begin{array}{c}51.63(41), \\
83.74(14), \\
82.31(14), 82.38(15)\end{array}$ & $80.21(10)$ & $76.23(12)$ & $52.39(20)$ \\
\hline $\begin{array}{l}\text { Tol torsion } \\
\text { angles }{ }^{b}\left({ }^{\circ}\right)\end{array}$ & $\begin{array}{c}74.72(15), 68.87(15) \\
\quad(\text { porphyrin 1)/ } \\
61.85(14), 74.98(11) \\
\quad(\text { porphyrin 2) }\end{array}$ & & & $\begin{array}{l}84.59(9) \\
88.69(9)\end{array}$ & $\begin{array}{l}66.69(17) \\
69.03(18)\end{array}$ \\
\hline$d\left(\mathrm{C}_{\text {meso }}-\mathrm{C}_{\mathrm{Ph}}\right)(\AA)$ & $\begin{array}{c}1.498(8), 1.485(7) \\
(\text { porphyrin 1)/ } \\
1.508(7), 1.508(8) \\
\text { (porphyrin 2) }\end{array}$ & $\begin{array}{l}1.495(7), 1.499(7) \\
1.502(9), 1.513(9)\end{array}$ & $1.502(4)$ & $\begin{array}{c}1.501(4)<d \\
<1.504(5)\end{array}$ & $\begin{array}{c}1.479(8)<\mathrm{d} \\
<1.500(8)\end{array}$ \\
\hline$d\left(\mathrm{C}_{\text {meso }}-\mathrm{C}_{\mathrm{Tol}}\right)(\AA)$ & $1.493(7), 1.488(8)$ & & & & \\
\hline $\begin{array}{l}\text { RMS deviation }^{c} \\
(\AA)\end{array}$ & $0.212 / 0.203$ & 0.419 & 0.251 & 0.0352 & 0.247 \\
\hline $\begin{array}{c}d(\mathrm{Co} 1 \cdots \mathrm{Co} 2) \\
(\AA)\end{array}$ & $5.2296(10)$ & $e$ & $e$ & $e$ & $e$ \\
\hline $\begin{array}{l}\text { Mean } \\
\text { planes porphyrin } \\
\text { Co1-Co2 } \\
\operatorname{angle}^{d}\left({ }^{\circ}\right)\end{array}$ & 21.09(4) & $e$ & $e$ & $e$ & $e$ \\
\hline density $\left(\mathrm{g} \cdot \mathrm{cm}^{-3}\right)$ & 1.417 & 1.422 & 1.404 & 1.37 & 1.415 \\
\hline
\end{tabular}

${ }^{a}$ Mean plane : mean plane calculated with the 4 nitrogen atoms of the porphyrin core. ${ }^{b}$ Angle between the mean plane $_{\text {porphyrin }}$ and the mean plane of the phenyl and tolyl groups. ${ }^{c}$ The RMS deviation corresponds to the root mean square of the distances of the 24 carbon and nitrogen porphyrin ring atoms from the mean plane formed by these atoms. ${ }^{d}$ Angle between the two mean planes of the 24 carbon and nitrogen porphyrin ring atoms. ${ }^{e}$ Not relevant.

Other $\mathrm{C}-\mathrm{H} \cdots \pi$ interactions between tolyl groups and pyrrole rings from the porphyrins also contribute to stabilize the crystallographic structure (Fig. 3). Thus the distance $d(\mathrm{C} 39$ $\mathrm{H} 39 \cdots$ centroid(C55-C56-C57-C58-N7) is 3.346(6) $\AA$ whereas distance $d(\mathrm{C} 71$ - 
$\mathrm{H} 71 \cdots$ centroid(C11-C12-C13-C14-N2) is equal to 3.664(7). The corresponding $\mathrm{C}-\mathrm{H} \cdots$ centroid angles are equal to $152.1(4)^{\circ}$ and $160.9(3)^{\circ}$, respectively.

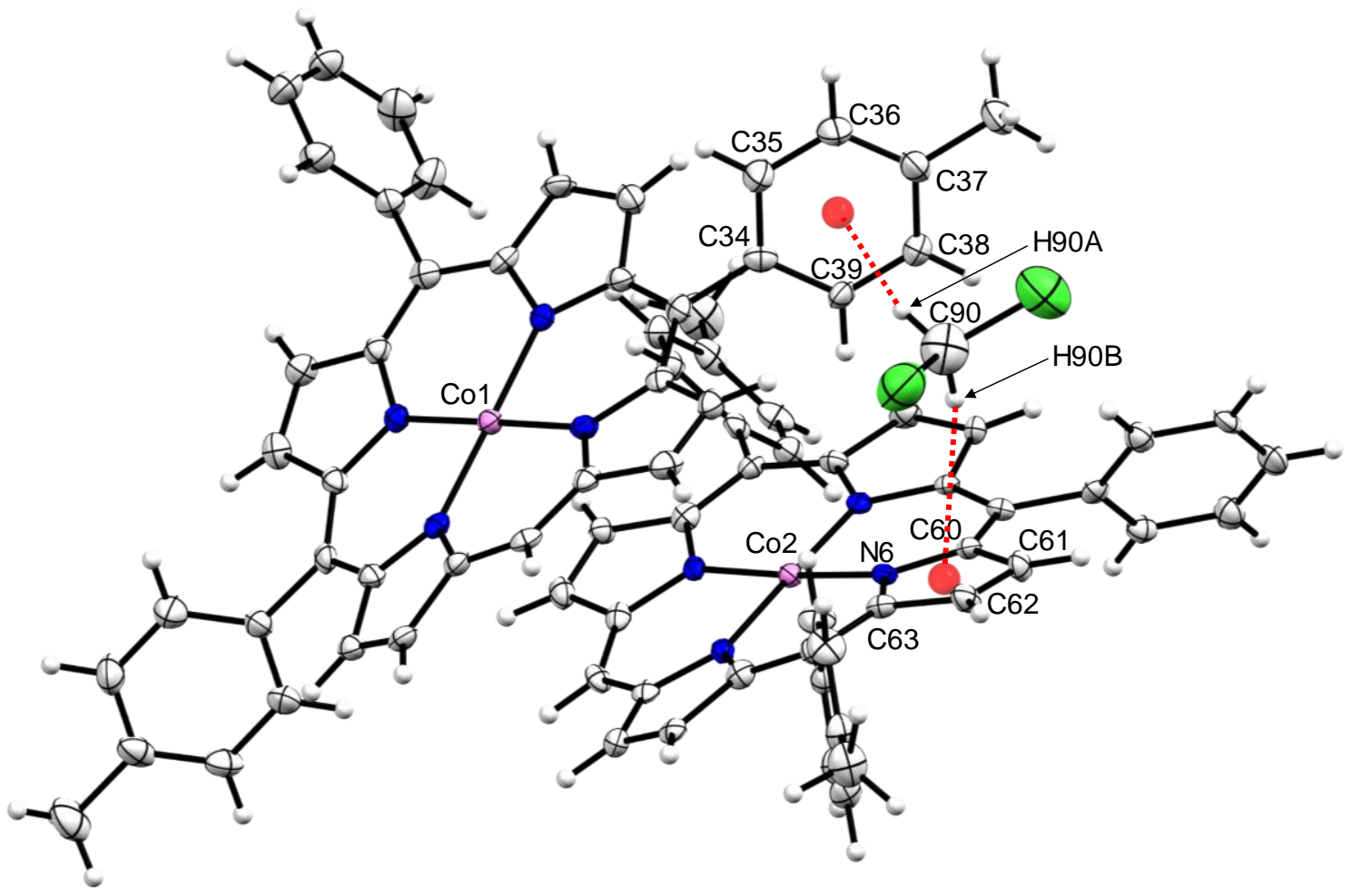

Fig. 2. Mercury view of 1-Co presenting the $\mathrm{C}-\mathrm{H} \cdots \pi$ interactions of $\mathrm{CH}_{2} \mathrm{Cl}_{2}$ with the tolyl ring of porphyrin $\mathbf{1}$ and with the pyrrole ring of porphyrin 2 [Color code: $\mathrm{C}$ grey, $\mathrm{N}$ blue, $\mathrm{Cl}$ green, $\mathrm{Co}$ pink, centroids red]. Thermal ellipsoids are scaled to the $50 \%$ probability level.

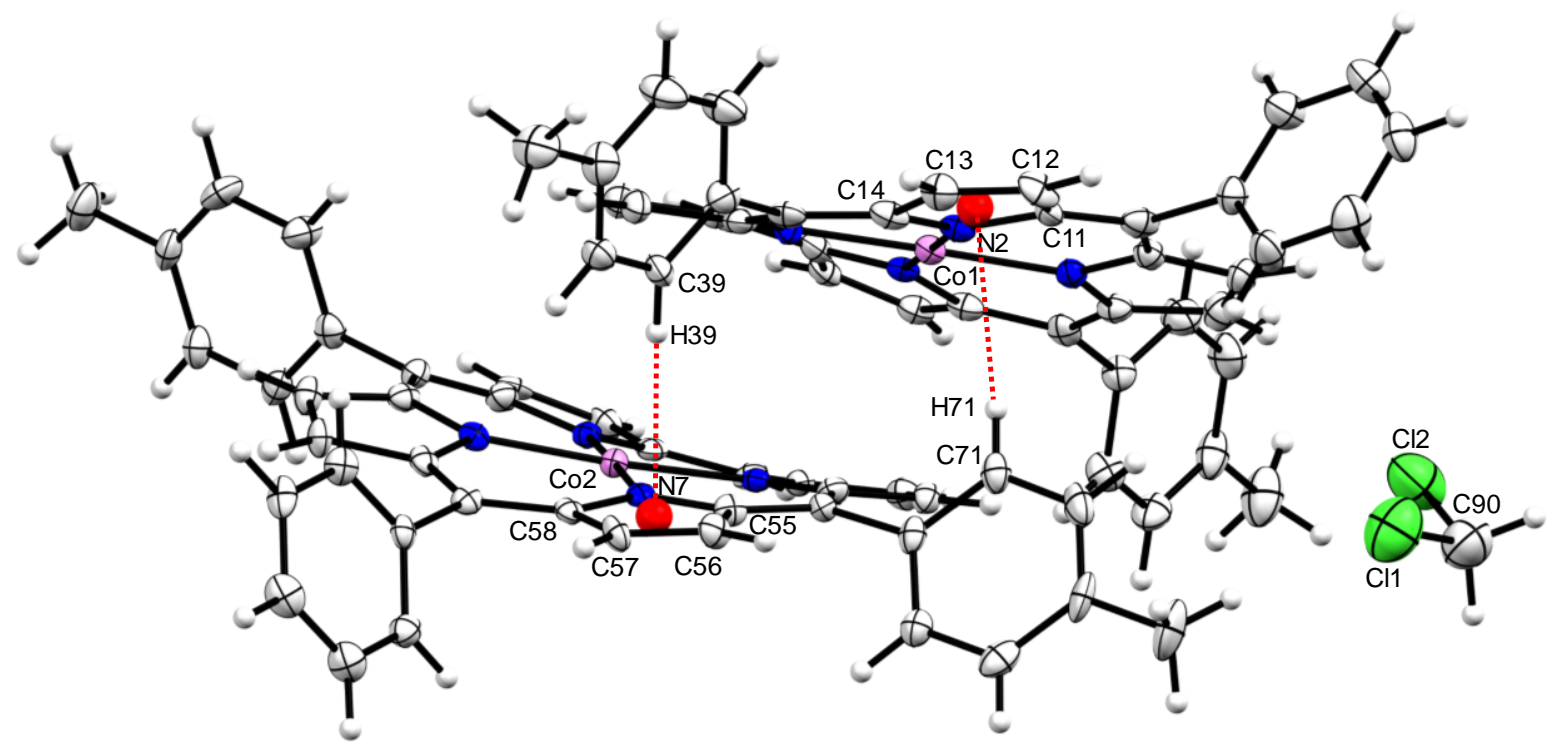

Fig. 3. Mercury view of 1-Co presenting the C-H $\cdots \pi$ interactions of $\mathrm{CH}_{2} \mathrm{Cl}_{2}$ with the tolyl ring of porphyrin $\mathbf{1}$ and with the pyrrole ring of porphyrin $\mathbf{2}$ [Color code: $\mathrm{C}$ grey, $\mathrm{N}$ blue, $\mathrm{Cl}$ green, Co pink, centroids red]. Thermal ellipsoids are scaled to the $50 \%$ probability level. 


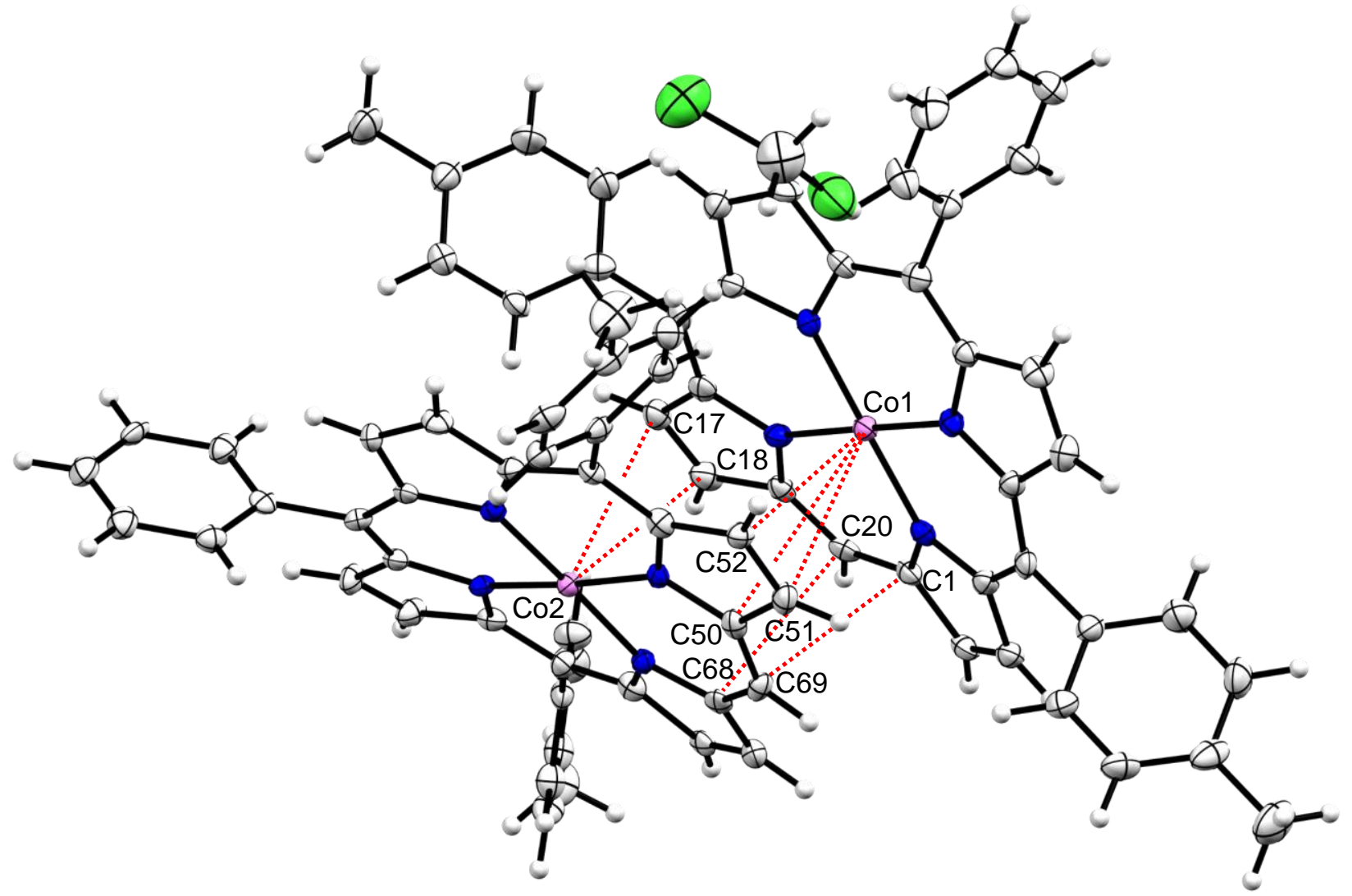

Fig. 4. Mercury view of 1-Co presenting the $\mathrm{Co}(\mathrm{II}) \cdots \pi$ and $\mathrm{C}$ (porphyrin 1)-C(porphyrin 2) interactions [Color code: $\mathrm{C}$ grey, $\mathrm{N}$ blue, $\mathrm{Cl}$ green, Co pink]. Thermal ellipsoids are scaled to the $50 \%$ probability level.

Remarkably, the Co(II) cation of the first porphyrin interacts with the $\pi$-system of the second porphyrin and vice versa (Fig. 4). This type of interactions has been previously reported for CoTPP.( $\left.\mathrm{CH}_{2} \mathrm{Cl}_{2}\right)_{0.6}$ [44]. For 1-Co the distances between the cobalt(II) atom Co1 (from porphyrin 1) and the carbon atoms C50, C51 and C52 from porphyrin 2 are 3.661(5), 3.349(6) and 3.446(5) $\AA$, respectively. Besides, the distances between the cobalt(II) atom Co2 (from porphyrin 2) and the carbon atoms $\mathrm{C} 17$ and $\mathrm{C} 18$ from porphyrin 1 are 3.489(6) and 3.664(6) $\AA$, respectively. By comparison, for $\mathbf{C o T P P} .\left(\mathbf{C H}_{2} \mathbf{C l}_{2}\right)_{0.6}$ the distances between the cobalt(II) atom Co1 and the carbon atoms C2 and C3 are significantly shorter (3.178(7) and 3.074(7) ^, respectively). The close porphyrin stacking is also strengthened by $\mathrm{C}$ (from porphyrin 1$) \cdots \mathrm{C}$ (from porphyrin 2) short interactions with $d(\mathrm{C} 68-\mathrm{C} 20)=3.274(8) \AA$ and $d(\mathrm{C} 69-\mathrm{C} 1)=3.278(7) \AA$.

Interestingly, 1-Co molecules form three pairs of stacked aromatics dimers obtained by inversion symmetry centers along the a-axis with an angle between the two porphyrins included in the asymmetric unit equal to $21.09(4)^{\circ}[47,48]$. Their slipped cofacial orientations resemble the 
molecular arrangement found in the photosynthetic special pair [49]. Besides, the centroid-tocentroid (calculated from the 24 carbon and nitrogen porphyrin ring atoms) distances between porphyrins are equals to 5.230 (asymmetric unit), 4.319 (porphyrin 2 and its symmetrical) and $4.391 \AA$ (porphyrin 1 and its symmetrical). Porphyrins are stacked in a non-parallel way along the a-axis, to form a pseudo-helical shape around the $\left[\begin{array}{lll}1 & 0 & 0\end{array}\right]$ direction (Fig. 5). The stacked porphyrin dimer formation might be favored by the absence of one meso-aryl substituent. 


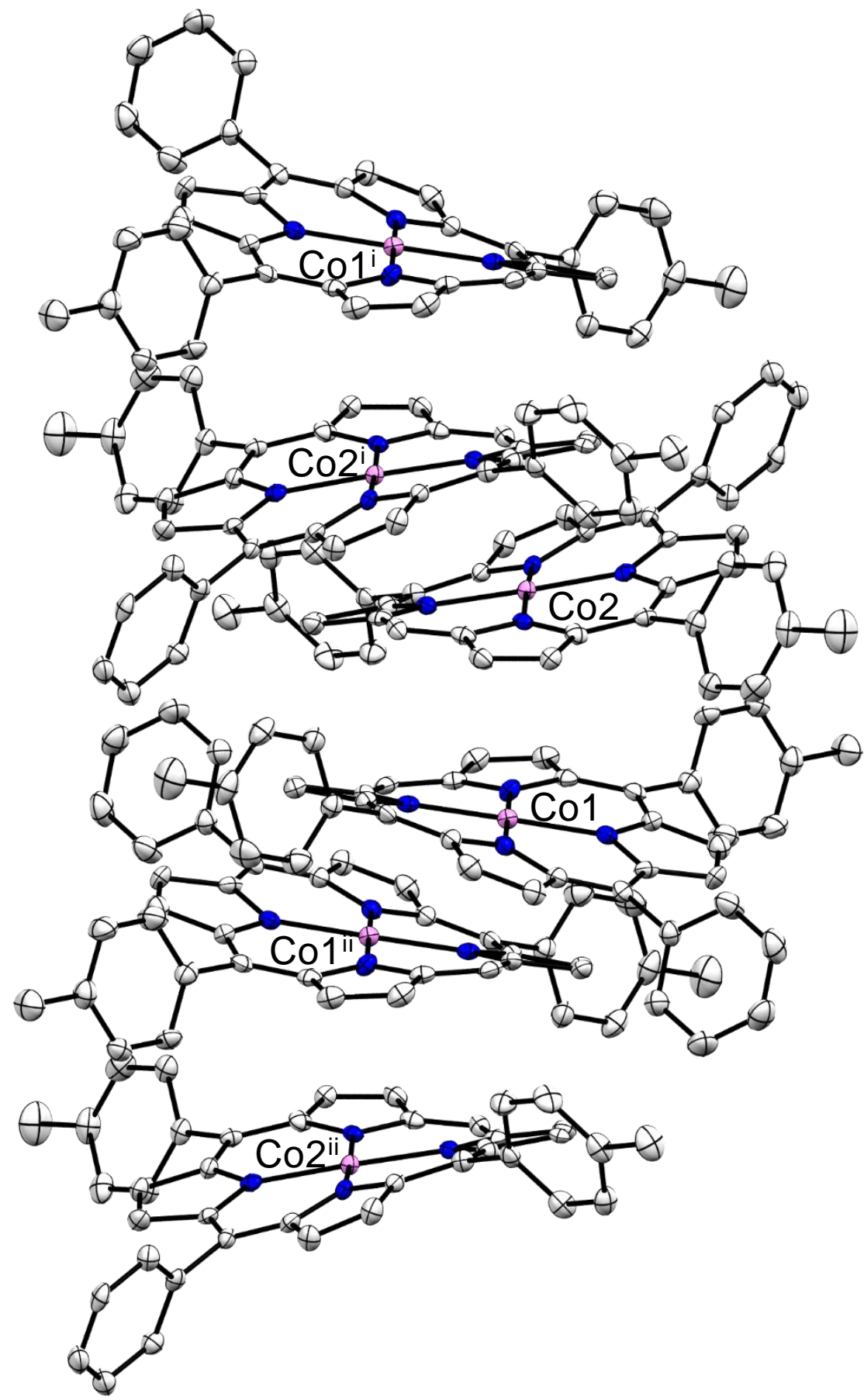

Fig. 5. View of the packing diagram of 1-Co along the $c$-axis [Color code: $\mathrm{C}$ grey, $\mathrm{N}$ blue, Co pink]. Displacement ellipsoids are drawn at the $50 \%$ probability level. Hydrogen atoms were omitted for clarity. Symmetry codes : (i) -x, $\mathrm{y},-\mathrm{z}$; (ii) $1-\mathrm{x},-\mathrm{y},-\mathrm{z}$. 


\subsection{Electrochemical characterization of $\mathbf{1 - C o}$}

The cyclic voltammogram (CV) of 1-Co in $\mathrm{CH}_{2} \mathrm{Cl}_{2} / \mathrm{CH}_{3} \mathrm{CN}$ mixture (2/3 v/v) $0.1 \mathrm{M}$ TEAPF 6 (Fig. 6) exhibits one monoelectronic irreversible metal centered oxidation $(\mathrm{Co}(\mathrm{II}) \rightarrow \mathrm{Co}(\mathrm{III}))$ at $E_{\mathrm{pa}}(\mathrm{O} 1)=0.44 \mathrm{~V}[31,50]$. The second redox process is reversible $\left(E_{1 / 2}(\mathrm{O} 2 / \mathrm{R} 2)=1.08 \mathrm{~V}, \Delta E_{\mathrm{p}}=70\right.$ $\mathrm{mV})$, but the third redox system is not $\left(E_{\mathrm{pa}}(\mathrm{O} 3)=1.49 \mathrm{~V}\right)$. Previously, Manassen attributed the redox-systems that were involved in the electrochemical oxidation of cobalt (II) mesotetraphenylporphyrin (CoTPP) [31]. Based on cyclic voltammetry investigations, these studies showed that the first oxidation peak was remarkably shifted to less positive potentials when coordinating solvents such as pyridine were added whereas other redox systems were less or not affected. Given the very close structural analogy of 1-Co with CoTPP, it was initially assumed that the first oxidation of 1-Co was centered on the metal $(\mathrm{Co}(\mathrm{II}) \rightarrow \mathrm{Co}(\mathrm{III}))$ rather than on the porphyrin ligand. Thus, the two monoelectronic subsequent oxidations are ligand centered and correspond to the formation of the cation-radical (peak system O2/R2) and the dication (O3/R3), respectively.

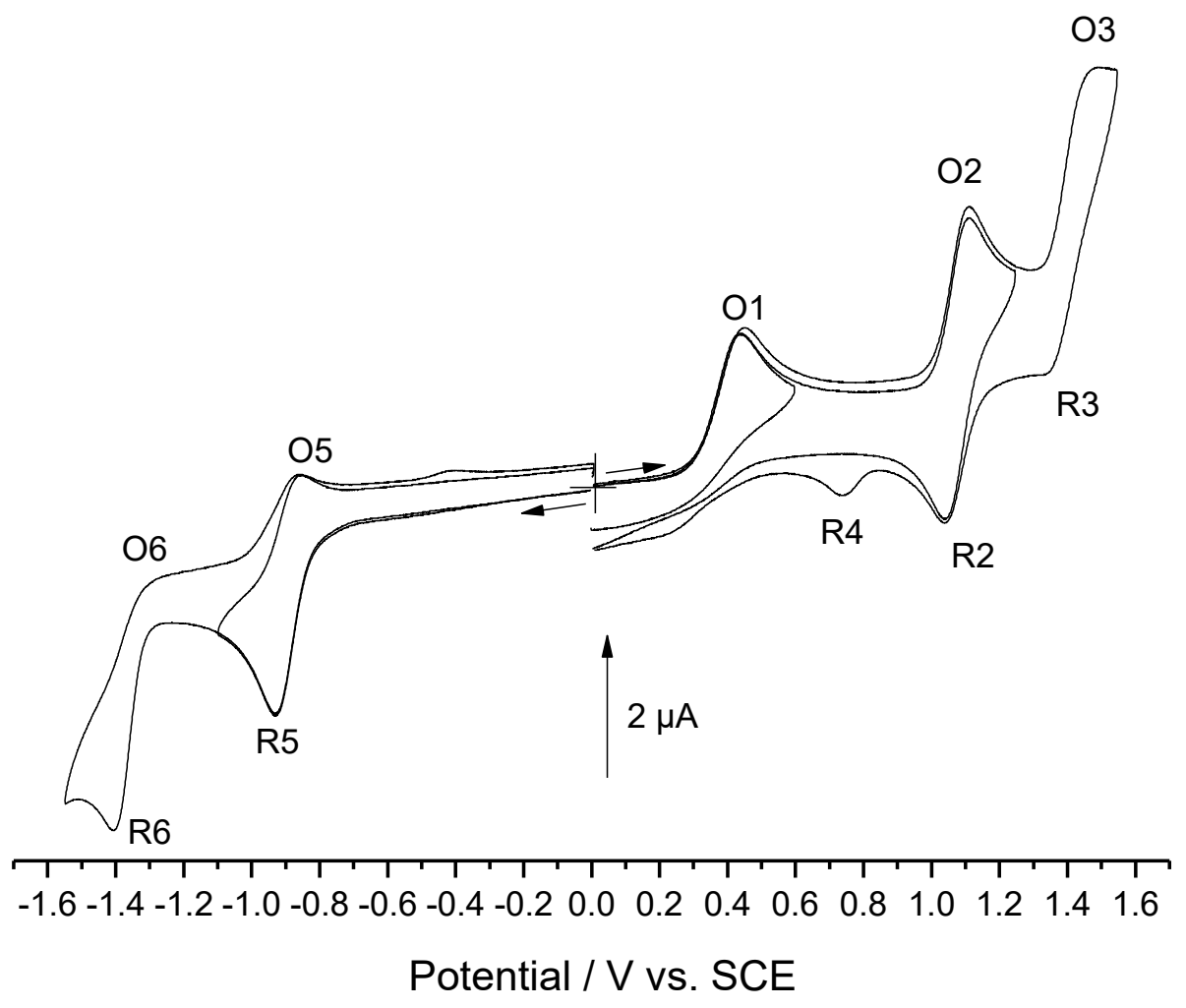

Fig. 6. Cyclic voltammograms of 1-Co in $\mathrm{CH}_{2} \mathrm{Cl}_{2} / \mathrm{CH}_{3} \mathrm{CN}\left(2 / 3 \mathrm{v} / \mathrm{v}\right.$ ) $0.1 \mathrm{M}$ TEAPF 6 (WE: $\mathrm{Pt}, \emptyset=2 \mathrm{~mm}, 0.1 \mathrm{~V} \mathrm{~s}{ }^{-1}$, $[\mathbf{1}$ Co $\left.]=5.0 \times 10^{-4} \mathrm{M}\right)$. 
As summarised in Table 3, the potential of the oxidation peaks principally depends on the metal inside the porphyrin as well as its peripheral substitution pattern. In the case of cobalt(II) or nickel(II) porphyrins, the two monoelectronic oxidations peaks of the macrocycle (second and third oxidations for the $\mathrm{Co}$ (II) porphyrins and first and second oxidations for the $\mathrm{Ni}$ (II) porphyrin) are significantly higher than the zinc(II) complex. This evolution matches well with what was previously reported for CoTPP, NiTPP and ZnTPP [51].

Table 3

Potential values ( $E_{1 / 2}$ or $E_{p}$ for irreversible systems) for 1-Co, CoTPP, 1-Zn and 1-Ni (in V vs SCE).

\begin{tabular}{cccccc}
\hline & \multicolumn{2}{c}{ Experimental conditions } & \multicolumn{2}{c}{ Oxidation } \\
\hline Compounds & Solvent & Electrolyte & $1 \mathrm{st}$ & $2 \mathrm{nd}$ & 3rd \\
1-Co & $\mathrm{CH}_{2} \mathrm{Cl}_{2} / \mathrm{CH}_{3} \mathrm{CN}(2 / 3 \mathrm{v} / \mathrm{v})$ & $0.1 \mathrm{M} \mathrm{TEAPF} 6$ & 0.44 & 1.08 & 1.49 \\
CoTPP [29] & $\mathrm{CH}_{2} \mathrm{Cl}_{2}$ & $0.1 \mathrm{M} \mathrm{TBAPa}$ & 0.75 & 0.98 & 1.16 \\
$\mathbf{1 - Z n ~ [ 3 4 ]}$ & $\mathrm{CH}_{2} \mathrm{Cl}_{2} / \mathrm{CH}_{3} \mathrm{CN}(4 / 1 \mathrm{v} / \mathrm{v})$ & $0.1 \mathrm{M} \mathrm{TBAPF} 6$ & 0.72 & 1.15 & - \\
$\mathbf{1 - N i}[35]$ & $\mathrm{CH}_{2} \mathrm{Cl}_{2} / \mathrm{CH}_{3} \mathrm{CN}(4 / 1 \mathrm{v} / \mathrm{v})$ & $0.1 \mathrm{M} \mathrm{TEAPF} 6$ & 1.03 & 1.25 \\
\hline
\end{tabular}

When the positive potential scan is reversed back just after peak $\mathrm{O} 3$, a new reduction peak is seen at $E_{\mathrm{pc}}(\mathrm{R} 4)=0.74 \mathrm{~V}$. This additional R4 peak could be tentatively attributed to the reduction of an oxidized dimer that is formed during the forward scan $[34,35]$. In the negative potential direction, the first monoelectronic pseudo-reversible peak $\left(E_{\mathrm{pc}}(\mathrm{R} 5)=-0.93 \mathrm{~V}, \Delta E_{\mathrm{p}}=80 \mathrm{mV}\right)$ is attributed to the $\mathrm{Co}(\mathrm{II}) \rightarrow \mathrm{Co}(\mathrm{I})$ transformation by comparison with other data from the literature [52]. The $\mathrm{CV}$ exhibits a second irreversible reduction at $E_{\mathrm{pc}}(\mathrm{R} 6)=-1.41 \mathrm{~V}$ which plausibly corresponds to the first reduction of the porphyrin ring. To confirm that the first oxidation system was correctly assigned, UV-visible spectro-electrochemical experiments were performed under argon, at room temperature, in a $\mathrm{CH}_{2} \mathrm{Cl}_{2} / \mathrm{CH}_{3} \mathrm{CN}$ mixture $(2 / 3 \mathrm{v} / \mathrm{v})$ containing $0.1 \mathrm{M}$ of $\mathrm{TEAPF}_{6}$ and 1-Co at a concentration of $[\mathbf{1 - C o}]=5.0 \times 10^{-4} \mathrm{M}$. The potential was set at a potential slightly more positive than peak $\mathrm{O} 1\left(E_{\mathrm{app}}=0.60 \mathrm{~V}\right)$. The current progressively decreased and finally reached the residual current value when $1.0 \mathrm{~F}$ per mol of 1-Co was transferred. Then, the RDE voltammogram of the resulting red solution (Fig. 7) no longer shows the initial monoelectronic O1 oxidation system, which gives evidence for complete conversion of 1-Co. The other monoelectronic oxidation processes $(\mathrm{O} 2$ and $\mathrm{O} 3)$ are similar to the ones observed before electrolysis of 1-Co (potential position and current magnitude). 


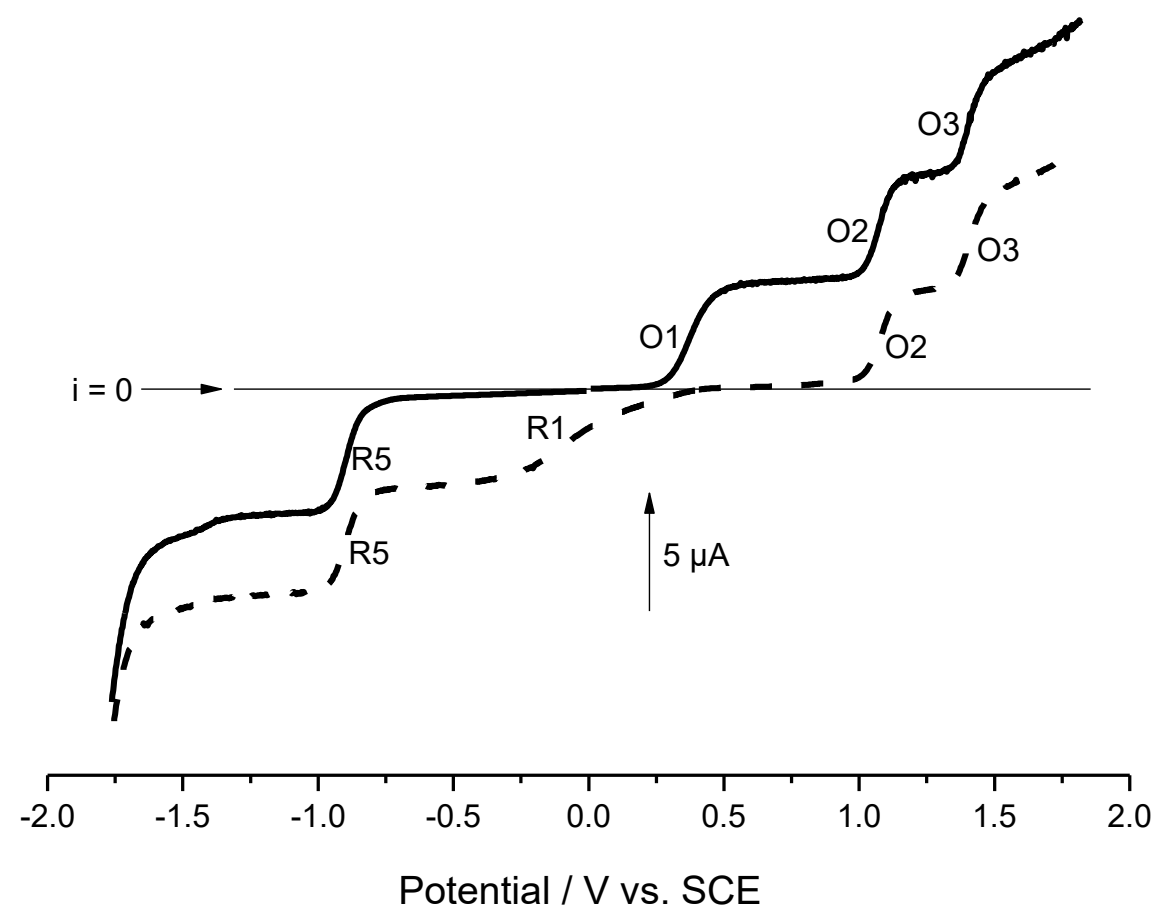

Fig. 7. $\mathrm{RDE}$ voltammograms of 1-Co in $\mathrm{CH}_{2} \mathrm{Cl}_{2} / \mathrm{CH}_{3} \mathrm{CN}(3 / 2 \mathrm{v} / \mathrm{v}) 0.1 \mathrm{M}$ TEAPF 6 . before (solid line) and after electrolysis (dashed line) (WE: Pt, $\varnothing=2 \mathrm{~mm}, 10 \mathrm{mV} \mathrm{s}^{-1}, \omega=500 \mathrm{rpm},[\mathbf{1 - C o}]=5.0 \times 10^{-4} \mathrm{M},-1.0 \mathrm{~F} / \mathrm{mol}$ of 1-Co).

An additional cathodic system centered around $0.00 \mathrm{~V}$ is attributed to the $\mathrm{Co}$ (III) $\rightarrow \mathrm{Co}$ (II) system which confirms the formation of 1-Co ${ }^{\text {III }}$ after the electrolysis. The evolution of the UVvisible absorption spectra was simultaneously monitored during the electrolysis. A representative evolution is displayed in Fig. 8. The Soret band foot underwent a progressive bathochromic shift, whereas the initial $\mathrm{Q}$ band at $\lambda=524 \mathrm{~nm}$ progressively disappears at the expense of two new $\mathrm{Q}$ bands at $\lambda=543$ and $576 \mathrm{~nm}$. Another band is also observed at higher energy $(\lambda=317 \mathrm{~nm})$. In another experiment, given the high molar extinction coefficient of the 1-Co Soret band, the concentration was decreased to $[\mathbf{1 - C o}]=2 \times 10^{-5} \mathrm{~mol} \mathrm{~L}^{-1}$ so that the maximum absorbance fell into the measurable spectrometer range. The initial Soret band of 1-Co $\left(\lambda_{\max }=407 \mathrm{~nm}\right)$ progressively disappears at the expense of a new band at $429 \mathrm{~nm}$. The presence of isosbestic points located at 419 and $534 \mathrm{~nm}$ confirms the simple transformation of the initial porphyrin into another welldefined product, i.e. 1-Co' ${ }^{\text {III }}$, with no intermediate observed between. During the first oxidation of 1-Co, the UV-visible absorption spectra evolution was very similar to those previously reported for CoTPP by Wolberg and Manassen in benzonitrile $\left(0.1 \mathrm{M} n-\mathrm{Bu}_{4} \mathrm{NClO}_{4}\right)$ [53] and by Jones and Hinman in $\mathrm{CH}_{2} \mathrm{Br}_{2} / \mathrm{CH}_{3} \mathrm{CN}$ (0.1 $\left.\mathrm{M} \mathrm{TBAPF}_{6}\right)$ [54]. 


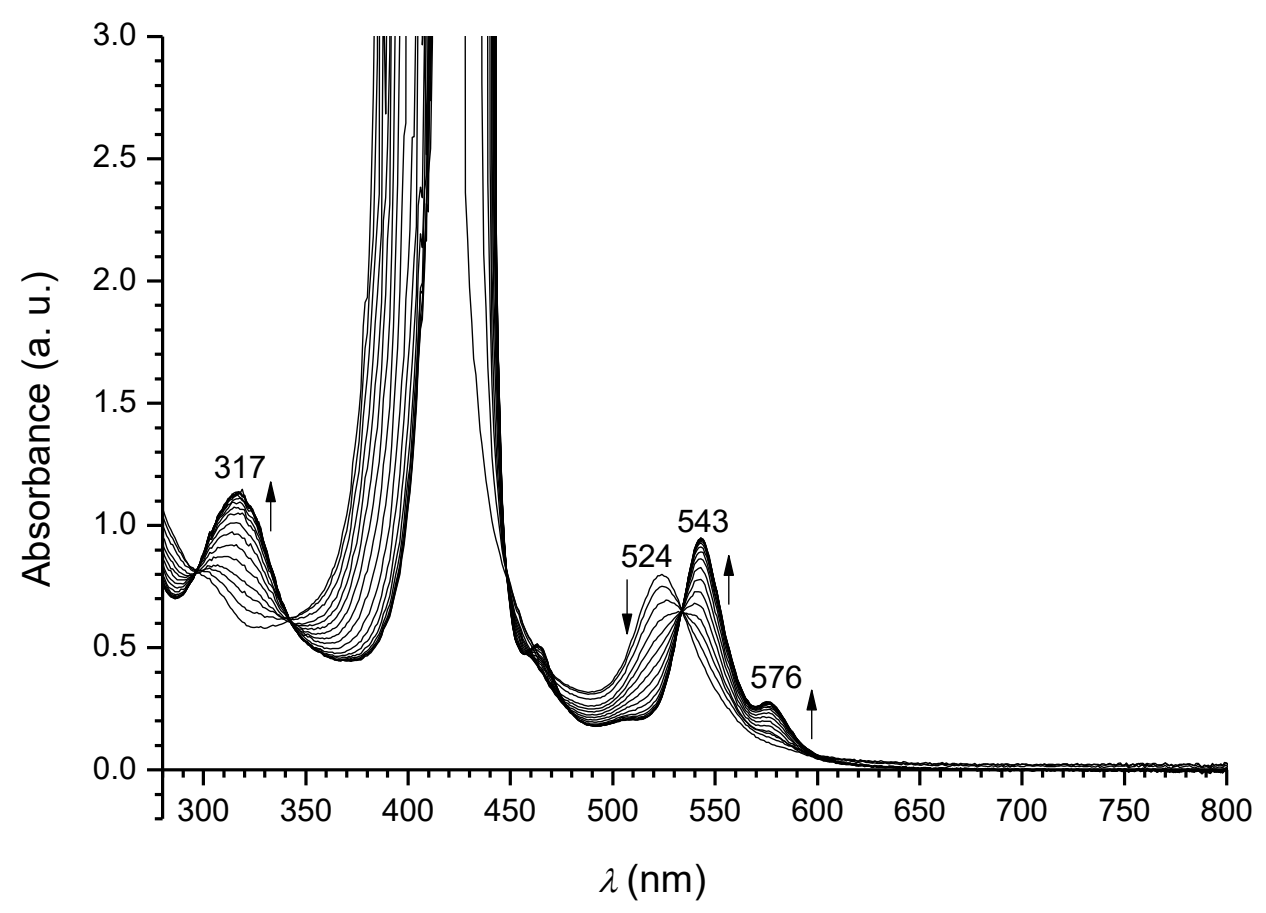

Fig. 8. Electrolysis of a $5.0 \times 10^{-4} \mathrm{M}$ solution of 1-Co followed by UV-vis spectroscopy $\left(l=2 \mathrm{~mm}, 0.1 \mathrm{M} \mathrm{TEAPF}_{6}\right.$ in $\mathrm{DCM} / \mathrm{ACN} 2 / 3 \mathrm{v} / \mathrm{v}, E_{\text {app }}=0.60 \mathrm{~V} v s$. SCE, -1 electron, WE: Pt wire, WE and counter-electrode are in separated compartments).

Based on EPR [55] and IR [54] analyses of the CoTPP first oxidation product, these authors demonstrated that this monoelectronic oxidation was reversible and centered on the metal and not on the porphyrin ring. Thus in our case the spectro-electrochemical experiment confirms again that this first oxidation concerns the reversible $\mathrm{Co}(\mathrm{II}) \rightarrow \mathrm{Co}(\mathrm{III})$ transformation.

\section{Conclusion}

In summary, the first monoelectronic oxidation of 1-Co was proved to be metal-centered (Co(II) $\rightarrow \mathrm{Co}(\mathrm{III})$ ) based on electrochemical and spectroelectrochemical studies and also by comparison with the results reported in the literature. The original X-ray crystallographic structure of 1-Co showed different kinds of interactions such as aromatic cycle stacking (stacked aromatics porphyrin dimers), $\mathrm{C}-\mathrm{H} \cdots \pi$ interactions between the dichloromethane molecule and the $\pi$-systems of tolyl and pyrrole rings, $\mathrm{C}-\mathrm{H} \cdots \pi$ interactions between tolyl groups and the $\pi$-systems of the porphyrins as well as $\operatorname{Co}(\mathrm{II}) \cdots \pi$ interactions between the cobalt(II) cations and the $\pi$-systems of the porphyrins. Also the stacked aromatics dimers arrange in a pseudo-helical manner. Our efforts are now focused on the electrochemical reactivity of 1-Co at higher potentials. 


\section{Acknowledgements}

This work was supported by the "CNRS, Université Bourgogne Franche-Comté, Conseil Régional de Bourgogne" through the "Plan d'Actions Régional pour l'Innovation (PARI)" and the "Fonds Européen de Développement Régional (FEDER)" programs. A.K.D.D. acknowledges the "Ministère de l'Enseignement Supérieur et de la Recherche" for a PhD grant and the "Université Alioune Diop de Bambey" for funding. C. H. D. thanks the CNRS (Sept. 2015, one year "délégation CNRS"), the ANR (ANR-15-CE29-0018-01) and the French "Investissement d'Avenir" program, project ISITE-BFC (contract ANR-15-IDEX03) for funding. The authors are thankful to Dr B. Habermeyer (PorphyChem Company) for generous gift of the 10-phenyl-5,15-di-p-tolylporphyrin sample and to S. Fournier for technical support.

\section{References}

[1] F.J. Kampas, K. Yamashita, J. Fajer, Photoelectrochemical properties of metalloporphyrins, Nature. 284 (1980) 40-42, https://doi.org/10.1038/284040a0.

[2] E. Song, C. Shi, F.C. Anson, Comparison of the behavior of several cobalt porphyrins as electrocatalysts for the reduction of $\mathrm{O}_{2}$ at graphite electrodes, Langmuir. 14 (1998) 43154321, https://doi.org/10.1021/la980084d.

[3] C. Bucher, C.H. Devillers, J.-C. Moutet, G. Royal, E. Saint-Aman, Self-assembly of a ferrocene-substituted porphyrin capable of electrochemically sensing neutral molecules via a tail on-tail off process, Chem. Commun. (2003) 888-889, https://doi.org/10.1039/b301177a.

[4] M.R. Wasielewski, Self-assembly strategies for integrating light harvesting and charge separation in artificial photosynthetic systems, Acc. Chem. Res. 42 (2009) 1910-1921, https://doi.org/10.1021/ar9001735.

[5] L. Wei, K. Padmaja, W.J. Youngblood, A.B. Lysenko, J.S. Lindsey, D.F. Bocian, Diverse redox-active molecules bearing identical thiol-terminated tripodal tethers for studies of molecular information storage, J. Org. Chem. 69 (2004) 1461-1469, https://doi.org/10.1021/jo0349476.

[6] S.H. Kazemi, B. Hosseinzadeh, S. Zakavi, Electrochemical fabrication of conducting polymer of Ni-porphyrin as nano-structured electrocatalyst for hydrazine oxidation, Sens. Actuators B-Chem. 210 (2015) 343-348, https://doi.org/10.1016/j.snb.2014.12.131.

[7 ] S. Ishihara, J. Labuta, W. Van Rossom, D. Ishikawa, K. Minami, J.P. Hill, K. Ariga, Porphyrin-based sensor nanoarchitectonics in diverse physical detection modes, Phys. Chem. Chem. Phys. 16 (2014) 9713-9746, https://doi.org/10.1039/C3CP55431G.

[8] S.-M. Chen, Y.-L. Chen, R. Thangamuthu, Electropolymerization of iron tetra(oaminophenyl)porphyrin from aqueous solution and the electrocatalytic behavior of modified electrode, J. Solid State Electrochem. 11 (2007) 1441-1448, https://doi.org/10.1007/s10008007-0315-3. 
[9] A. Gómez-Caballero, A. Ugarte, A. Sánchez-Ortega, N. Unceta, M.A. Goicolea, R.J. Barrio, Molecularly imprinted poly[tetra(o-aminophenyl)porphyrin] as a stable and selective coating for the development of voltammetric sensors, J. Electroanal. Chem. 638 (2010) 246-253, https://doi.org/10.1016/j.jelechem.2009.11.006.

[10] E. Mazzotta, C. Malitesta, Electrochemical detection of the toxic organohalide 2,4-DB using a Co-porphyrin based electrosynthesized molecularly imprinted polymer, Sens. Actuators BChem. 148 (2010) 186-194, https://doi.org/10.1016/j.snb.2010.03.089.

[11] A.C. Paske, L.D. Earl, J.L. O’Donnell, Interfacially polymerized metalloporphyrin thin films for colorimetric sensing of organic vapors, Sens. Actuators B-Chem. 155 (2011) 687-691, https://doi.org/10.1016/j.snb.2011.01.030.

[12] L. Lvova, C. Di Natale, R. Paolesse, Porphyrin-based chemical sensors and multisensor arrays operating in the liquid phase, Sens. Actuators B-Chem. 179 (2013) 21-31, https://doi.org/10.1016/j.snb.2012.10.014.

[13] A. Wong, M.D.P.T. Sotomayor, Biomimetic sensor based on 5,10,15,20tetrakis(pentafluorophenyl)-21H,23H-porphyrin iron (III) chloride and MWCNT for selective detection of 2,4-D, Sens. Actuators B-Chem. $181 \quad$ (2013) 332-339, https://doi.org/10.1016/j.snb.2012.12.095.

[14] C.-W. Kung, T.-H. Chang, L.-Y. Chou, J.T. Hupp, O.K. Farha, K.-C. Ho, Porphyrin-based metal-organic framework thin films for electrochemical nitrite detection, Electrochem. Commun. 58 (2015) 51-56, https://doi.org/10.1016/j.elecom.2015.06.003.

[15] S.D. Rolle, D.V. Konev, C.H. Devillers, K.V. Lizgina, D. Lucas, C. Stern, F. Herbst, O. Heintz, M.A. Vorotyntsev, Efficient synthesis of a new electroactive polymer of $\mathrm{Co}$ (II) porphine by in-situ replacement of $\mathrm{Mg}(\mathrm{II})$ inside $\mathrm{Mg}(\mathrm{II})$ polyporphine film, Electrochim. Acta. 204 (2016) 276-286, https://doi.org/10.1016/j.electacta.2016.03.039.

[16] H. Huang, W. Song, J. Rieffel, J.F. Lovell, Emerging applications of porphyrins in photomedicine, Front Phys. 3 (2015), https://doi.org/10.3389/fphy.2015.00023.

[17] M. Jurow, A.E. Schuckman, J.D. Batteas, C.M. Drain, Porphyrins as molecular electronic components of functional devices, Coord. Chem. Rev. 254 (2010) 2297-2310, https://doi.org/10.1016/j.ccr.2010.05.014.

[18] T.E.O. Screen, I.M. Blake, L.H. Rees, W. Clegg, S.J. Borwick, H.L. Anderson, Making conjugated connections to porphyrins: A comparison of alkyne, alkene, imine and azo links, J. Chem. Soc., Perkin Trans. 1. (2002) 320-329, https://doi.org/10.1039/B109915A.

[19] C. Erben, S. Will, K.M. Kadish, Metallocorroles: Molecular structure, spectroscopy and electronic itates, in: The porphyrin Handbook, academic press, Kadish, K. M., Smith, K. M. \& Guilard, R., San Diego, CA, 2000: pp. 233-300.

[20] R. Paolesse, Syntheses of corroles, in: The porphyrin Handbook, academic press, Kadish, K. M., Smith, K. M., \& Guilard, R., San Diego, CA, 2000: pp. 201-232.

[21] F.C. Anson, C. Shi, B. Steiger, Novel multinuclear catalysts for the electroreduction of dioxygen directly to water, Acc. Chem. Res. 30 (1997) 437-444, https://doi.org/10.1021/ar960264j.

[22] C.J. Chang, Z.-H. Loh, C. Shi, F.C. Anson, D.G. Nocera, Targeted proton delivery in the catalyzed reduction of oxygen to water by bimetallic pacman porphyrins, J. Am. Chem. Soc. 126 (2004) 10013-10020, https://doi.org/10.1021/ja049115j.

[23] E. Mutti, M. Hunger, S. Fedosov, E. Nexo, B. Kräutler, Organometallic DNA-B 12 conjugates as potential oligonucleotide vectors: synthesis and structural and binding studies with human 
cobalamin-transport proteins, ChemBioChem. $18 \quad$ (2017) 2280-2291, https://doi.org/10.1002/cbic.201700472

[24] K. Oohora, N. Tang, ·Y. Morita, T. Hayashi, Cobalt tetradehydrocorrins coordinated by imidazolate-like histidine in the heme pocket of horseradish peroxidase, J. Biol. Inorg. Chem. 5 (2017) 695-703, https://doi.org/10.1007/s00775-017-1458-z.

[25] K. Tahara, L. Pan, T. Ono, Y. Hisaeda, Learning from B12 enzymes: biomimetic and bioinspired catalysts for eco-friendly organic synthesis, Beilstein. J. Org. Chem. 14 (2018) 2553-2567, https://doi.org/10.3762/bjoc.14.232.

[26] Marjorie Sonnay and Felix Zelder, Stabilizing intramolecular cobalt-imidazole coordination with a remote methyl group in the backbone of a cofactor B12-protein model, Dalton

Trans., 47 (2018) 10443-10446, https://doi.org/10.1039/C8DT01298A.

[27] K. Laba, M. Lapkowski, D.L. Officer, P. Wagner, P. Data, Electrochemical and optical aspects of cobalt meso-carbazole, Electrochim. Acta., 330 (2020) 135140- 135150, https://doi.org/10.1016/j.electacta.2019.135140

[28] Ali, W. Akram, H. Liu, Reactive cobalt-oxo complexes of tetrapyrrolic macrocycles and Nbased ligand in oxidative transformation reactions, Molecules. 24, (2019) 78-94, https://doi.org/10.3390/molecules24010078.

[29] X. Ke, R. Kumar, M. Sankar, K.M. Kadish, Electrochemistry and spectroelectrochemistry of cobalt porphyrins with $\pi$-extending and/or highly electron-withdrawing pyrrole substituents. in situ electrogeneration of $\sigma$-bonded complexes, Inorg. Chem. 57 (2018) 1490-1503, https://doi.org/10.1021/acs.inorgchem.7b02856.

[30] N. Chaudhri, Ray J. Butcherb, M. Sankar, Synthesis and structural, photophysical, electrochemical redox and axial ligation properties of highly electron deficient perchlorometalloporphyrins and selective $\mathrm{CN}$ sensing by $\mathrm{Co}$ (II) complexes, New J. Chem., 42 (2018) 8190-8199, https://doi.org/10.1039/C7NJ04418F.

[31] J. Manassen, Modification of the redox-properties of tetraphenylporphyrin-complexes by bases in methylene-chloride solution. The equilibrium of different oxidation-states with added base as measured by cyclic voltammetry, Isr. J. Chem. 12 (1974) 1059-1067, https://doi.org/10.1002/ijch.197400101.

[32] C.H. Devillers, D. Lucas, A.K.D. Dimé, Y. Rousselin, Y. Mugnier, Exploring the redox reactivity of magnesium porphine. Insight into the origins of electropolymerisation, Dalton Trans. 39 (2010) 2404-2411, https://doi.org/10.1039/b914916c.

[33] C.H. Devillers, A.K.D. Dimé, H. Cattey, D. Lucas, Electrochemical meso-functionalization of magnesium(ii) porphine, Chem. Commun. 47 (2011) 1893-1895, https://doi.org/10.1039/c0cc04309e.

[34] A.K.D. Dimé, C.H. Devillers, H. Cattey, B. Habermeyer, D. Lucas, Control over the oxidative reactivity of metalloporphyrins. Efficient electrosynthesis of meso,meso-linked zinc porphyrin dimer, Dalton Trans. 41 (2012) 929-936, https://doi.org/10.1039/c1dt11330e.

[35] A.K.D. Dimé, C.H. Devillers, H. Cattey, D. Lucas, Versatile redox reactivity of triaryl-mesosubstituted Ni(ii) porphyrin, Dalton Trans. 43 (2014) 14554-14564, https://doi.org/10.1039/c4dt00221k.

[36] O.I. Istakova, D.V. Konev, A.S. Zyubin, C.H. Devillers, M.A. Vorotyntsev, Electrochemical route to $\mathrm{Co}(\mathrm{II})$ polyporphine, J. Solid State Electrochem. 20 (2016) 3189-3197, https://doi.org/10.1007/s10008-016-3397-y.

[37] S.D. Rolle, C.H. Devillers, S. Fournier, O. Heintz, H. Gibault, D. Lucas, A glassy carbon electrode modified by a triply-fused-like Co(ii) polyporphine and its ability for sulphite 
oxidation and detection, New J. Chem. $42 \quad$ (2018) 8180-8189, https://doi.org/10.1039/C7NJ04370H.

[38] D.V. Konev, O.I. Istakova, B. Dembinska, M. Skunik-Nuckowska, C.H. Devillers, O. Heintz, P.J. Kulesza, M.A. Vorotyntsev, Electrocatalytic properties of manganese and cobalt polyporphine films toward oxygen reduction reaction, J. Electroanal. Chem. 816 (2018) 8391, https://doi.org/10.1016/j.jelechem.2018.03.042.

[39] C.H. Devillers, S. Hebié, D. Lucas, H. Cattey, S. Clément, S. Richeter, Aromatic nucleophilic substitution (SNAr) of meso-nitroporphyrin with azide and amines as an alternative metal catalyst free synthetic approach to obtain meso-N-substituted porphyrins, J. Org. Chem. 79 (2014) 6424-6434, https://doi.org/10.1021/jo5005586.

[40] A. Altomare, G. Cascarano, C. Giacovazzo, A. Guagliardi, Completion and refinement of crystal structures with SIR92, J. Appl. Crystallogr. 26 (1993) 343-350, https://doi.org/10.1107/S0021889892010331.

[41] G.M. Sheldrick, Crystal structure refinement with SHELXL, Acta Crystallogr. C71 (2015) 38, https://doi.org/10.1107/S2053229614024218.

[42] L.J. Farrugia, WinGX suite for small-molecule single-crystal crystallography, J. Appl. Crystallogr. 32 (1999) 837.-838, https://doi.org/10.1107/S0021889899006020.

[43] K.M. Kadish, L. Frémond, J. Shen, P. Chen, K. Ohkubo, S. Fukuzumi, M. El Ojaimi, C.P. Gros, J.-M. Barbe, R. Guilard, Catalytic activity of biscobalt porphyrin-corrole dyads toward the reduction of dioxygen, Inorg. Chem. 48 (2009) 2571-2582, https://doi.org/10.1021/ic802092n.

[44] C.C. de Melo, W. da C. Moreira, T.J. Martins, M.R. Cordeiro, J. Ellena, F.F. Guimarães, F.T. Martins, Saddle-shaped macrocycle distortion and symmetry decrease in cobalt (II) mesotetraphenylporphyrin: Structure of a dichloromethane solvate and DFT calculations, J. Mol. Struct. 1076 (2014) 468-474, https://doi.org/10.1016/j.molstruc.2014.08.001.

[45] B.F.O. Nascimento, M. Pineiro, A.M. d'A. Rocha Gonsalves, M. Ramos Silva, A. Matos Beja, J.A. Paixão, Microwave-assisted synthesis of porphyrins and metalloporphyrins: A rapid and efficient synthetic method, J. Porphyrins Phthalocyanines. 11 (2007) 77-84, https://doi.org/10.1142/S1088424607000102.

[46] M. Nishio, The $\mathrm{CH} / \pi$ hydrogen bond in chemistry. Conformation, supramolecules, optical resolution and interactions involving carbohydrates, Phys. Chem. Chem. Phys. 13 (2011), 13873-13900, https://doi.org/10.1039/c1cp20404a

[47] W.-T. Chen, Structure and photophysical and electrochemical properties of a copper porphyrin complex with a three-dimensional framework, Acta Cryst. C76 (2020) 133-138, https://doi.org/10.1107/S2053229619017273.

[48] W.-T. Chen, A one-dimensional manganese(III)-porphyrin coordination polymer: crystal structure and photophysical properties, Acta Cryst. C76 (2020), 375-380, https://doi.org/10.1107/S2053229620004350.

[49] J. Deisenhofer, H. Michel, The photosynthetic reaction center from the purple bacterium Rhodopseudomonas viridis, Science. $245 \quad$ (1989) 1463-1473, https://doi.org/10.1126/science.245.4925.1463.

[50] L.A. Truxillo, D.G. Davis, Electrochemistry of cobalt tetraphenylporphyrin in aprotic media, Anal. Chem. 47 (1975) 2260-2267, https://doi.org/10.1021/ac60363a052.

[51] K. M. Kadish, E. V. Caemelbecke, G. Royal, in The Porphyrin Handbook, Vol. 8 (Eds.: K. M. Kadish, K. M. Smith, R. Guilard), Academic Press, San Diego, 2000, pp. 1-114. 
[52] F.A. Walker, D. Beroiz, K.M. Kadish, Electronic effects in transition metal porphyrins. 2. The sensitivity of redox and ligand addition reactions in para-substituted tetraphenylporphyrin complexes of cobalt(II), J. Am. Chem. Soc. 98 (1976) 3484-3489, https://doi.org/10.1021/ja00428a016.

[53] A. Wolberg, J. Manassen, Electrochemical and electron paramagnetic resonance studies of metalloporphyrins and their electrochemical oxidation products, J. Am. Chem. Soc. 92 (1970) 2982-2991, https://doi.org/10.1021/ja00713a010.

[54] D.H. Jones, A.S. Hinman, In situ infrared spectroelectrochemical studies of tetraphenylporphyrin complexes containing manganese, iron and cobalt, Dalton Trans. (1992) 1503-1508, https://doi.org/10.1039/DT9920001503.

[55] A. Wolberg, J. Manassen, Electrochemical and electron paramagnetic resonance studies of metalloporphyrins and their electrochemical oxidation products, J. Am. Chem. Soc. 92 (1970) 2982-2991, https://doi.org/10.1021/ja00713a010. 